\title{
連続水制を伴う開水路乱流における自由水面の ガス輸送に関する基礎的研究
}

\author{
FUNDAMENTAL STUDY ON INTERFACIAL GAS TRANSFER IN OPEN- \\ CHANNEL FLOW WITH A SERIES OF SPUR DIKES
}

\author{
崎谷健太 ${ }^{1} \cdot$ 山上路生 2 \\ Kenta SAKITANI and Michio SANJOU \\ 1学生会員 京都大学大学院修士課程 工学研究科社会基盤工学専攻（†615-8540 京都市西京区京都大学桂） \\ 2正会員 博(工) 京都大学准教授 工学研究科社会基盤工学専攻（干615-8540 京都市西京区京都大学桂)
}

\begin{abstract}
In this study, gas transfer velocity through free surface is investigated in open channel flow with a series of spur dikes. Spur dikes formed closed dead-water zones between the neighboring members. The slow-speed circulation observed in such cavity zones is quite different from high-speed mainstream. Therefore, the cavity zones and the mainstream are assumed to have different reaeration coefficient. The reaeration coefficients are evaluated by means of laboratory measurements. The measurement theory is also specially developed together with consideration of gas transfer through the junction between main-channel / side-cavity. It is found out from present results that reaeration coefficient depends strongly on the aspect ratio (width/length) of dead water zones under same hydraulic condition.
\end{abstract}

Key Words : gas transfer, spur dikes, groyne field, mass exchange and open-channel flow

\section{1. はじめに}

河川水域では豊かでダイナミックな生態系が形成され る. 近年河川工学は，この河川生態の保全，回復と治水 の両立を社会的に求められている. このような状況で, 航路の確保や護岸目的で古くから使用されている水制工 が河川養生，ビオトープの創出の観点から用いられるよ うになっている.

連続水制はその領域内凹部において死水域を生じ，凹 部と主流部との間のせん断不安定性のために大規模な水 平渦を生ずる. 中川ら によよるとアルミ紛懸濁法による 流れの可視化により，死水域開口部において組織的な水 平渦がほぼ一定周期で生じ，せん断層を流下しながら渦 どうしが合体し，周囲の流体を取り込みながら次第に成 長するとしている．また，せん断不安定性による渦とセ イシュの発生周期や共鳴現象について，木村ら ${ }^{2)}$ は数值 計算によって，大本・平川 $3^{33)}$ 4実験によってそれぞれ 鋭意検討している. 藤田ら 底面に近づく程流れの3次元性が強まること, 剥離せん 断層における運動量と渦度の輸送に関してTaylorの凍結 乱流仮説がほぼ成立すること及び剥離せん断層内には複 数の低周波運動が存在することを示した。また彼らは LESによる数值計算も行い，凹部内流速変動の低周波成
分が再現できること, 剥離せん断層から離脱した渦は底 面付近において横断方向に幅を持つ2次元的構造となる ことを示した．禰津らのは死水域のアスペクト比を系統 的に変化させた流れ場をPIVによって計測し，死水域の アスペクト比によって死水域周辺の流れ場が大きく変化 することを示している.

連続水制による死水域と主流部は，平均流では互いに 独立しているように見える。しかし上記の水平渦の効果 により質量交換がなされている(例えば八木7), 冨永ら ${ }^{8)}$ など). この質量交換の定量的な研究はValentine and Wood $^{9}$ の栈粗度流れにおける鉛直方向の質量交換の研究 を基にUijttewaal et al. ${ }^{10}$ によって水平方向の交換に応用さ れ, Weitbrecht et al. ${ }^{11)}$ によって系統的な計測がなされて いる. このモデルでは質量交換の速度は死水域のジオメ トリー及び主流部の断面平均流速で与えられる。 また Contantinuscu et al. ${ }^{12)}$ はアスペクト比1の連続水制の物質交 換について数值計算し，連続水制の物質交換速度は上下 流それぞれの死水域で大きな差がないことに言及してい る.

河川養生，ビオトープの創出の目的で水制工が用いら れる場合，水質の管理が必要となり，水質の要素に溶存 酸素がある. 実河川における溶存酸素の増減は呼吸・光 合成等の生化学作用と, 気液界面を通じるガス輸送等の 
物理作用に起因するが，本研究では自由水面における物 理作用に着目する.

ガス輸送に関する基礎研究は比較的古くから行われて おり, 多くのガス輸送速度に関するモデルが提案されて きた ${ }^{13) 144 .}$ 。た，ガス輸送を支配する乱流現象の研究も 盛んに行われている. Komori et $\mathrm{al}^{15}$. は, 開水路において 流れ場の計測を行い，底面で発生するバースティングが ガス輸送に強く関わっていることを指摘している．また Moog \& Jirka ${ }^{16}$ は水理条件を系統的に変化させた開水路 でガス輸送速度の計測を行い，バースティングと共に自 由水面近傍の散逸率に代表される細かな渦構造の重要性 を指摘している. 一方, Tsumori \& Sugihara ${ }^{17}$ は振動格子 タンクにおいてPIVとLIF計測を行い，散逸率よりも大き な, テイラーのマイクロスケールの現象であると指摘し ており, 平山ら ${ }^{18)}$ も攪拌槽での実験で散冕率スケールの 小さな渦よりは，乱れ強度に代表される大きな渦の方が 現象をよく再現できるとしている．また開水路，振動格 子タンクにおいて, レイノルズ数により現象が遷移ある いは分岐する可能性が既往研究(Moog \& Jirka ${ }^{10}$, Herlina \& Jirka $\left.{ }^{19}\right)$ により指摘されている.

本研究では，連続水制によって生じる死水域と主流部 では異なるガス輸送速度をもつと考え，またこれにより 死水域と主流部で濃度差が生じ, 溶存気体の輸送が発生 する可能性も考慮して, 連続水制を伴う開水路でのばっ 気速度の計測を試みる.

\section{2. 連続水制場におけるガス輸送の理論考察}

本論文では気液境界面において, 気相から液相一の難 溶性気体が輸送される現象を取り扱う。気相，液相とも に気液境界面近傍では濃度境界層が生じており, 濃度境 界層内での濃度変化は急激である，一方，境界面から十 分に離れた領域では乱流混合により濃度分布は一様であ ると考えられる.この領域をバルク領域と呼ぶ。 ガス交 換はこのバルク領域と濃度境界層の濃度差が駆動力とな り行われる. したがってガス交換速度は気相で定義され る交換速度と液相で定義される交換速度が存在する．難 溶性気体を対象とする場合，ガス交換のフラックスは液 相の抵抗に支配され気相と液側濃度境界層は常に平衡状 態にあると考えられる.これにより難溶性気体のガス交 換現象は気液二相間の濃度輸送問題から, 液側の常に一 定の濃度を持つ気液境界面とバルク層間での濃度輸送問 題へと簡略化できる. 以上よりガス輸送による濃度変化 はバルク層の濃度 $C_{b}$ と気液境界面の濃度 $C_{S}$ を用いて,

$$
\frac{d C_{b}}{d t}=k_{2}\left(C_{S}-C_{b}\right)
$$

となる. ここで $k_{2}$ は再ばっ気係数と呼ばれ $[1 / T]$ の次元 をもち、ばっ気速度を代表する。

水制を伴う開水路においては，水制により生じるの死
水域と主流部とでは流れ場が大きく異なるため, それぞ れ異なるガス輸送速度を持つと考えられる. また，二つ の領域でガス輸送速度が異なると二つの領域間で濃度差 が生じ，それにより領域間で物質輸送が生じる. 二つの 領域での物質交換が十分大きい速度で行われるのならば, それぞれの領域の濃度を体積で重み付け平均寸れば混合 後の濃度が適切に求まるが，水制による死水域と主流部 は平均流で見ると独立しており，その濃度輸送を無視す る事は出来ない可能性がある.

まず死水域内のバルク濃度 $C_{G}$ の変化を考える. $C_{G}$ は 死水域一気液界面から流入した濃度の総量 $C_{G}{ }^{*}$ と物質交 換により流入した濃度の総量 $C_{e x}$ を変数とする関数で表 されるとする. 寸ると $C_{G} の d t$ 時間当たりの変化は高次の 項を無視して

$$
\frac{d C_{G}}{d t}=\frac{\partial C_{G}}{\partial C_{G}^{*}} \frac{d C_{G}^{*}}{d t}+\frac{\partial C_{G}}{\partial C_{e x}} \frac{d C_{e x}}{d t}
$$

と表される. ここで $\partial C_{G} / \partial C_{G}^{*}$ 及び $\partial C_{G} / \partial C_{e x}$ は $C_{G}^{*}$ 及び $C_{e x}$ が単位量変化した場合の $C_{G}$ の変化量であるから, こ の場合は共に1となる。

次に主流部の濃度 $C_{M}$ の変化を考える. 式(1)は閉鎖系 に対して求められた式と考えるべきであるが，主流部は 開放系である. したがって $C_{M}$ はある速度(例えば平均流 速)で流下寸るある体積の濃度と考える方が良い。これ に伴い $C_{G}$ の定義を, 濃度 $C_{M}$ をもつ流体塊に死水域で併 走する仮想的な流体塊の濃度と取り替え， $C_{G}{ }^{*}$ をその流 体塊一の気液界面からの総流入量, $C_{e x}$ を流体塊同士で の物質交換による死水域への総流入量とする. この定義 の取替えにより, 式(2)およびその前後の議論に変更はな い. また $C_{M}$ につて, 主流部一の気液境界面からの総 流入量を $C_{M}{ }^{*}$ とすると $C_{G}$ の時間変化と同様に,

$$
\frac{d C_{M}}{d t}=\frac{\partial C_{M}}{\partial C_{M}^{*}} \frac{d C_{M}^{*}}{d t}+\frac{\partial C_{M}}{\partial C_{e x}} \frac{d C_{e x}}{d t}
$$

と書ける. ただし $\partial C_{M} / \partial C_{M}^{*}$ は1であるが， $\partial C_{M} / \partial C_{e x}$ は死水域，主流部それぞれの体積を $V_{G}, V_{M}$ として平均的 にー $V_{G} / V_{M}$ となる.

Weitbrecht et al. ${ }^{11)}$ によると, 死水域の主流部との濃度 交換による濃度増加 $d C_{e x}$ の $d t$ 時間あたりの変化は次式で 与えられる。

$$
\frac{d C_{e x}}{d t}=k_{D}\left(C_{M}-C_{G}\right)
$$

式(4)での $C_{G}$ はひとつの死水域の平均濃度で, 本論文で 
与えている定義と異なる. しかし本論分では死水域のジ オメトリーが流下方向に変化しないので $k_{D}$ な定である ことが期待され，物質交換を式(4)で表しても大きな差は 生じないとした.

気液界面での物質輸送については，死水域と主流部で それぞれ $k_{2 G}, k_{2 M}$ という再ばっ気係数をもち，式(1)に従 うと仮定した。これらをまとめると以下の様になる.

$$
\left\{\begin{array}{l}
\frac{d C_{G}^{*}}{d t}=k_{2 G}\left(C_{S}-C_{G}\right) \\
\frac{d C_{M}^{*}}{d t}=k_{2 M}\left(C_{S}-C_{M}\right) \\
\frac{d C_{e x}}{d t}=k_{D}\left(C_{M}-C_{G}\right)
\end{array}\right.
$$

式(5)を式(2)及び式(3)に代入し、 $\left(V_{G} / V_{M}\right) k_{D}=k_{D}{ }^{\prime}$ とす ると、

$$
\left\{\begin{array}{l}
\frac{d C_{G}}{d t}=-\left(k_{2 G}+k_{D}\right) C_{G}+k_{2 G} C_{S}+k_{D} C_{M} \\
\frac{d C_{M}}{d t}=-\left(k_{2 M}+k_{D}^{\prime}\right) C_{M}+k_{2 M} C_{S}+k_{D}^{\prime} C_{G}
\end{array}\right.
$$

と連立一階微分方程式となる。これを解いて， $d\left(C_{S}-C_{G}\right)=-d C_{G}, d\left(C_{S}-C_{M}\right)=-d C_{M}$ に注意すると, ばっ気と濃度交換による濃度の变化は

$$
\left\{\begin{array}{r}
\frac{d^{2}\left(C_{S}-C_{G}\right)}{d t^{2}}+\left(k_{2 M}+k_{2 G}+k_{D}+k_{D}^{\prime}\right) \frac{d\left(C_{S}-C_{G}\right)}{d t} \\
+\left(k_{2 G} k_{2 M}+k_{2 G} k_{D}^{\prime}+k_{D} k_{2 M}\right)\left(C_{S}-C_{G}\right)=0 \\
\frac{d^{2}\left(C_{S}-C_{M}\right)}{d t^{2}}+\left(k_{2 M}+k_{2 G}+k_{D}+k_{D}^{\prime}\right) \frac{d\left(C_{S}-C_{M}\right)}{d t} \\
\quad+\left(k_{2 G} k_{2 M}+k_{2 G} k_{D}^{\prime}+k_{D} k_{2 M}\right)\left(C_{S}-C_{M}\right)=0
\end{array}\right.
$$

となる.

開水路での再ばっ気係数 $k_{2}$ の計測は以下のような方法 で行われている. 式(1)の一般解は積分定数を $A$ とすると,

$$
\frac{C_{S}-C_{b}}{C_{S}}=A \exp \left(-k_{2} t\right)
$$

と表される. 式(8)は $C_{S}$ で無次元化されたものであり，以 後式(8)の左辺をDと表現する.この式(9)の両辺に自然対 数をとり，時間で微分をとると，

$$
-\frac{d \ln D}{d t}=k_{2}
$$

ここで，常微分を偏微分に見かけ上変換すると，

$$
-\frac{\partial \ln D}{\partial t}-\frac{\partial \ln D}{\partial x} \frac{d x}{d t}=k_{2}
$$

となる. 左辺第1項は濃度の時間変化より，第2項は上下 流異なる点での濃度差より求まり，また定数となるため, 上下流 2 箇所の計測により再ばっ気係数 $k_{2}$ を求めること ができる(禰津・中山ら $\left.{ }^{20)}\right)$.

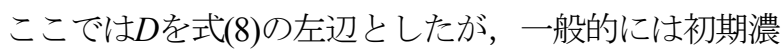
度 $C_{0}$ を用いた

$$
D=\frac{C_{S}-C_{b}}{C_{S}-C_{0}}
$$

が用いられる. 式(8)の左辺を式(11)の右辺とすれば, $A=1$ とすることが出来るが，Dの定義をどちらにしても 式(9)は成り立ち，そこから求まる再ばっ気係数も当然同 じである. また以下に示す式(12)において式(11)をDの定 義とする必然性がない。したがって本論文では1から飽 和度を引いたものという物理的な意味がはっきりしてい る式(8)の左辺をDの定義として採用する.

水制群を伴う開水路では，その濃度変化の一般解は式 (7)より,

$$
D=A_{1} \exp \left(-\alpha_{1} t\right)+A_{2} \exp \left(-\alpha_{2} t\right)
$$

となる.ここで $A_{1}, A_{2}$ は積分定数， $\alpha_{1}, \quad \alpha_{2}$ は式(7)の特 性方程式

$$
\begin{aligned}
\alpha^{2}-\left(k_{2 M}\right. & \left.+k_{2 G}+k_{D}+k_{D}^{\prime}\right) \alpha \\
& +\left(k_{2 G} k_{2 M}+k_{2 G} k_{D}^{\prime}+k_{D} k_{2 M}\right)=0
\end{aligned}
$$

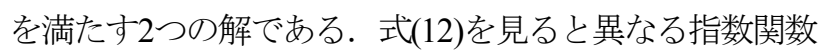
の和であるから式(8)から式(9)までの変形が不可能で あって，従来の方法の適応に疑問が生じる.

ところで $\alpha_{1}, \quad \alpha_{2}$ は二次関数である式(13)の解である. 従って, もし

$$
\begin{aligned}
\left(k_{2 M}+k_{2 G}+\right. & \left.k_{D}+k_{D}^{\prime}\right)^{2} \\
& >>4\left(k_{2 G} k_{2 M}+k_{2 G} k_{D}^{\prime}+k_{D} k_{2 M}\right)
\end{aligned}
$$

がいえれば二次関数の解の性質より $\alpha_{1}, \quad \alpha_{2}$ の内一方は 非常に0に近い值をとり，また他方の解は比較的十分大 きな解をもつ. Uijttewaal et al. ${ }^{10)}$ やWeitbrecht et al. ${ }^{11)}$ によ ると $k_{D}$ は $10^{-2}[\mathrm{~cm} / \mathrm{s}]$ 程度の大ささであり, 禰津・中山ら ${ }^{20)}$ や山上ら ${ }^{21)}$ によると開水路における $k_{2}$ は $10^{-4}[\mathrm{~cm} / \mathrm{s}]$ 程度の 
表-1 水理条件

\begin{tabular}{|c|c|c|c|c|c|c|c|c|}
\hline No. & $B_{G} L_{G}$ & $\begin{array}{c}L_{G} \\
(\mathrm{~cm})\end{array}$ & $\begin{array}{c}B_{G} \\
(\mathrm{~cm})\end{array}$ & $\begin{array}{c}B_{M} \\
(\mathrm{~cm})\end{array}$ & $\begin{array}{c}h \\
(\mathrm{~cm})\end{array}$ & $\begin{array}{c}U_{M} \\
(\mathrm{~cm} / \mathrm{s})\end{array}$ & $F \mathrm{r}$ & $R e$ \\
\hline 1 & 1.0 & 5 & \multirow{5}{*}{5} & \multirow{5}{*}{34} & \multirow{5}{*}{5} & \multirow{5}{*}{12} & \multirow{5}{*}{0.17} & \multirow{5}{*}{5917} \\
\hline 2 & 0.71 & 7 & & & & & & \\
\hline 3 & 0.45 & 11 & & & & & & \\
\hline 4 & 0.33 & 15 & & & & & & \\
\hline 5 & 0.16 & 31 & & & & & & \\
\hline
\end{tabular}

大きさである．したがって式(14)左辺は $10^{-2} \sim 10^{-4}[\mathrm{~cm} / \mathrm{s}]$ 程 度の大きさを持ち, 右辺は $10^{-7} \sim 10^{-8}[\mathrm{~cm} / \mathrm{s}]$ 程度の大きさを 持つと考えられる. よって式(14)が成立することが十分 期待できる.

式(14)が成り立つならば，式(13)の2つの解は，片方が 0に近い值をもち，もう片方はそれより十分大きな值を もつので, 式(12)左辺の 2 項それぞれの収束速度は大きく 異なる. したがって, 初期状態から十分時間が経過した 後は式(12)は以下のように近似できる.

$$
D=A_{1} \exp \left(-\alpha_{1} t\right)+A_{2} \exp \left(-\alpha_{2} t\right) \approx A \exp (-\alpha t)
$$

式(8)と式(15)を比較すると，ちょうど $k_{2}$ とを入れ替え た形になっているので，この $\alpha$ は連続水制を伴う開水路 の再ばっ気係数とみなせる. またこの $\alpha$ は開水路での再 ばっ気係数の計測と同様の方法で計測できる.ここでの $\alpha$ は

$$
\begin{aligned}
& \alpha=\frac{1}{2}\left\{k_{2 G}+k_{2 M}+k_{D}+k_{D}^{\prime}-\right. \\
& \left.\sqrt{\left(k_{2 G}+k_{2 M}+k_{D}+k_{D}^{\prime}\right)^{2}-4\left(k_{2 G} k_{2 M}+k_{2 G} k_{D}^{\prime}+k_{D} k_{2 M}\right)}\right\}
\end{aligned}
$$

である.これを式(14)の仮定の下，一次近似すると

$$
\alpha \approx \frac{k_{2 G} k_{2 M}+k_{2 G} k_{D}^{\prime}+k_{D} k_{2 M}}{k_{2 G}+k_{2 M}+k_{D}+k_{D}^{\prime}}
$$

となる。

\section{3. 実験方法}

実験は京都大学桂キャンパスの乱流水理実験室に設置 されたマルチフェイズ循環式水槽を用いて行った. 水路

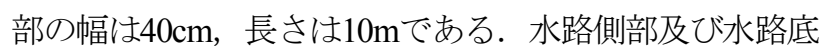
面計測部が強化ガラス製で，その他はスチール製である. この水路の中央部片側側面より $1 \mathrm{~cm}$ ところにアクリル 製の仕切り版を流下方向に990cmにわたって設置し，仕 切り版にアクリル製のブロックを設置することで連続水 制を再現した. アクリルブロックは幅 $5 \mathrm{~cm}$, 高さ7 $\mathrm{cm}$, 厚さ $1 \mathrm{~cm}$ で，水制のジオメトリーによって32個から 165

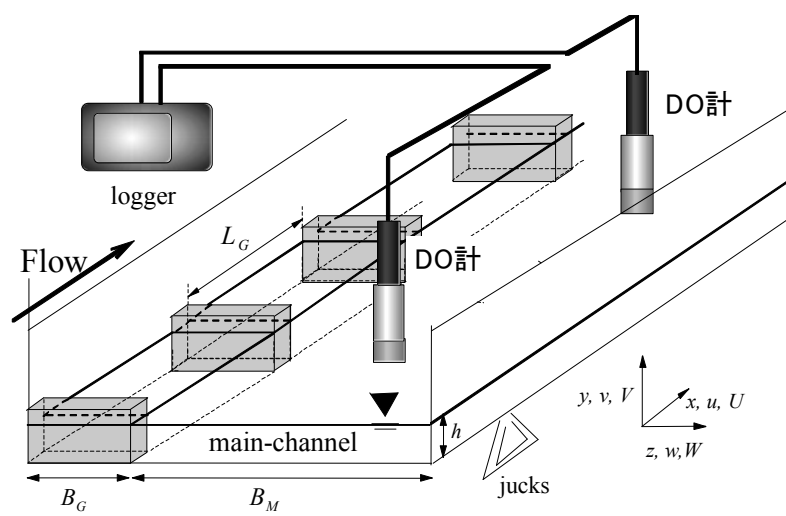

図-1＼cjkstart実験装置図

個を990cmの仕切り版に敷き詰めた.

水制模型は, 主流部幅 $B_{M}=34 \mathrm{~cm}$, 水制幅 $B_{G}=5 \mathrm{~cm}$ で, 水制は水路床，側壁に対して垂直に設置し，不透過，非 越流である. 水制間隔 $L_{G}$ は, $5 \mathrm{~cm}, 7 \mathrm{~cm}, 11 \mathrm{~cm}, 15 \mathrm{~cm}$, $32 \mathrm{~cm}$ の 5 種類とした. これを水制間のアスペクト比(水制 幅/水制間隔， $\left.B_{G} / L_{G}\right)$ で表すとそれぞれ，1，0.71，0.45， $0.33 ， 0.16$ となる. 水制間の流れ場はこのアスペクト比 毎に特徵づけされており, 襧津ら $\left.(2001)^{6}\right)$ にると, $B_{G} / L_{G}=1$ のとき単一の水平循環流, $B_{G} / L_{G}=0.33$ のとき二渦 対流の循環流が生じ, $B_{G} / L_{G}=0.2$ では乱れが強まり明確 な循環流の存在が確認できなくなり， $B_{G} / L_{G}=0.1$ では側 壁への再付着が生じるとされている。これを基に実験 ケースを決定し, 単一循環流が生じるケース $\left(B_{G} / L_{G}=1\right)$, 二渦対流の循環流が生じるケース $\left(B_{G} / L_{G}=0.33\right)$, これら の間のケース $\left(B_{G} / L_{G}=0.71, B_{G} / L_{G}=0.45\right)$, 循環流が生じな いケース $\left(B_{G} / L_{G}=0.16\right) の$ 全5ケースとした. 水制内と主流 部の水路床は平坦で段差はなく, 勾配は $1 / 1000$ とし，ま た水深 $h=5 \mathrm{~cm}$, 主流部の断面平均流速 $U_{M}=12 \mathrm{~cm} / \mathrm{s}$ とした. また水温はエアコンで外気を調節することによって $19.5^{\circ} \mathrm{C}$ とた. 速度次元に断面平均流速 $U_{M}$, 長さ次元に 水深 $h$ を選んだ場合, フルード数は 0.17 , 動粘性係数を 水温 $19.5^{\circ} \mathrm{C}$ 時の值 $0.01014 \mathrm{~cm}^{2} / \mathrm{s}$ とするとレイノルズ数は 5917である. これらの水理条件を表-1にまとめて示寸.

本研究では水制を伴う開水路のガス交換速度を測定す るために水路上流側及び下流側での溶存酸素( $\mathrm{DO})$ のバル ク濃度を測定した．図-1に実験装置図を示す．主流部中 央, 半水深の濃度が主流部のバルク濃度を代表するとし て，東亞DKK社製DO計を用いて計測した．観測地点は水 制領域の上流端から $40 \mathrm{~cm}$ の地点と $890 \mathrm{~cm}$ の地点とした. 計測では，まず無水亜硫酸ナトリウムで水槽中のDOが ほぼ $0 \mathrm{mg} /$ lになるまで酸素を消費し, 気液界面でのガス 輸送によって上昇していく $\mathrm{DO}$ 濃度を, その変化がなく なるまで計測した。計測時間は30〜36時間程度で，計測 結果はDO計に接続されたLoggerによって1Hzで自動的に 記録された. 

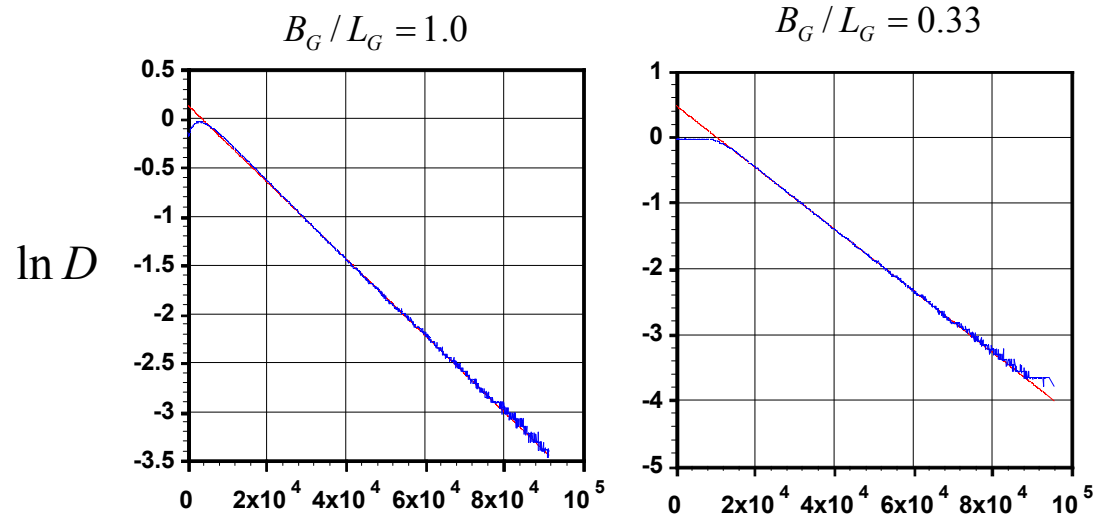

$\mathrm{t}(\mathrm{s})$

図-2 DOの時間変化

$$
B_{G} / L_{G}=1.0
$$

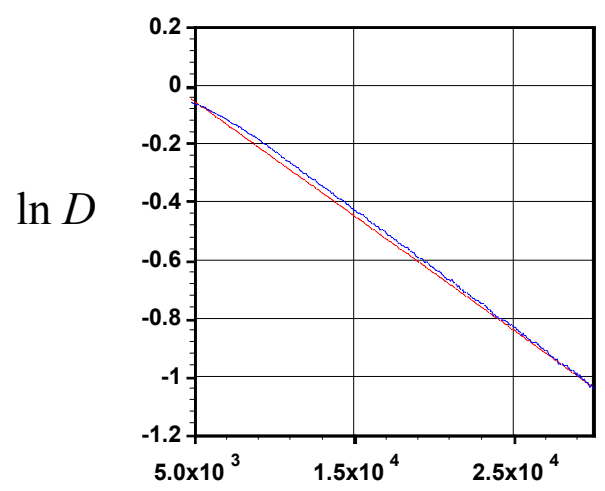

$B_{G} / L_{G}=0.33$

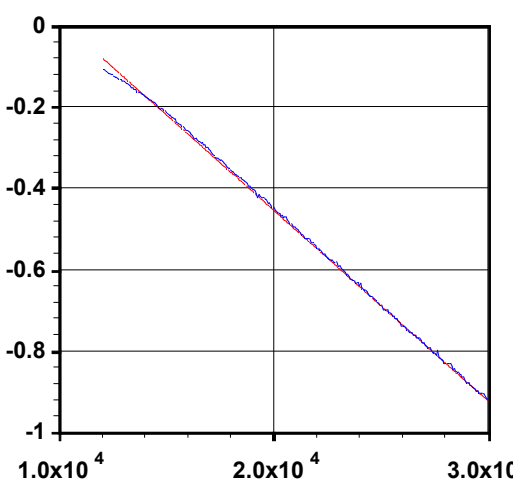

$\mathrm{t}(\mathrm{s})$
$B_{G} / L_{G}=0.16$

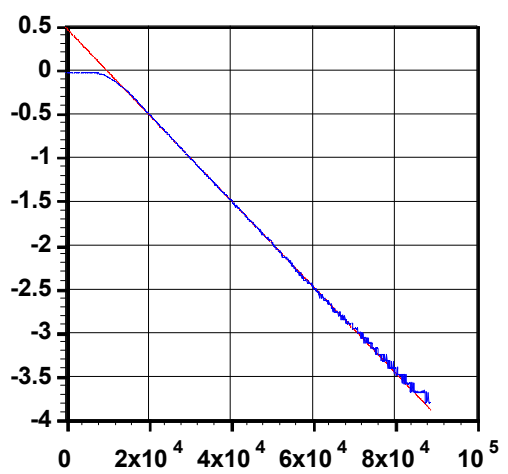

$B_{G} / L_{G}=0.16$

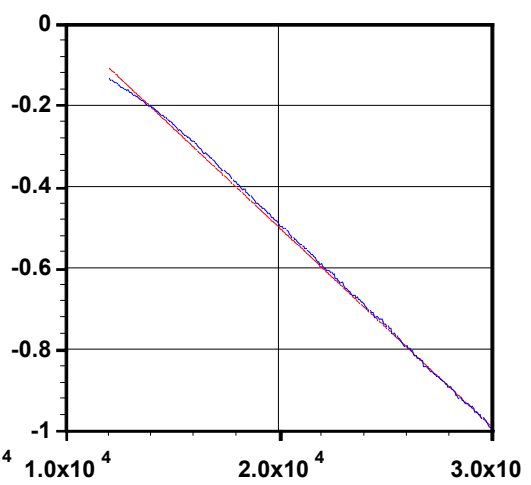

図-3 初期変化に着目したDOの時間変化

\section{4. 実験結果}

図-2は $B_{G} / L_{G}=1.0,0.33,0.16$ のケースで下流側のDO計 から得られた時系列データである. 座標は片対数で, 青 いラインが計測結果，赤いラインが $0.1<D<0.5$ の区間で 最小二乗法によって近似した直線である。計測結果は $0.05<D<1$ の範囲で示してある. 概観として近似直線とよ く一致している. また，初期の濃度変化に着目した図を 図-3に示寸，青いライン，赤いラインはそれぞれ図-2と 同様である. 最も収束が遅い $B_{G} / L_{G}=1.0$ のケースでも $\ln D=-0.9$, 寸なわち $D=0.41$ では収束している. これより 飽和度 $60 \%$ 以上の時，式(15)は十分成り立っていると考 えられる。

溶存酸素の指数変化が確認されたので, 式(10)によっ て再ばっ気係数を算出することができる. 左辺第 1 項の $\partial \ln D / \partial t$ は時系列データの傾き, 第2項の $\partial \ln D / \partial x$ は同時刻における上下流の計測值の差を観測地点間の距 離 $(850 \mathrm{~cm})$ で除したもの, $d x / d t$ は断面平均流速 $U_{M t}$ と
して算出した。 この時, 時系列データの傾きは上下流の 計測点でそれぞれわずかに異なる值を示すので，その平 均值を $\partial \ln D / \partial t$ とし，この傾きをもつ直線で時系列 データを再度近似し，その切片の差を $\partial \ln D / \partial x$ を求 める際の同時刻における計測值の差とした.

この方法によって算出した再ばっ気係数 $k_{2}$ を図-4に示 寸．アスペクト比と再曝気係数の間に反比例の関係があ るようにみえるが, $B_{G} L_{G}=0.33$ のケースが例外となって いる。 これに関しては $B_{G} / L_{G}=0.33$ のケースの再計測を 行ったがおよそ同様の值を示しており，計測ミスによる ズレではなさそうである．また $B_{G} L_{G}=0.33$ のースが小 さな值を示すことによって $B_{G} / L_{G}=0.45$ のケースにおいて 極大值を取っているが，その必然性は現在研究中である. アスペクト比が0の場合は水制が設置されていない状態 と考えられ，アスペクト比が非常に大きくなった場合も 水制を設置していない滑面状態に近付くと思われる. し たがって, 再曝気係数がアスペクト比に対して連続的で なめらかな変化をするならば最大值を持つことが期待さ れるが，本研究で扱った範囲には最大值は現れなかった。 


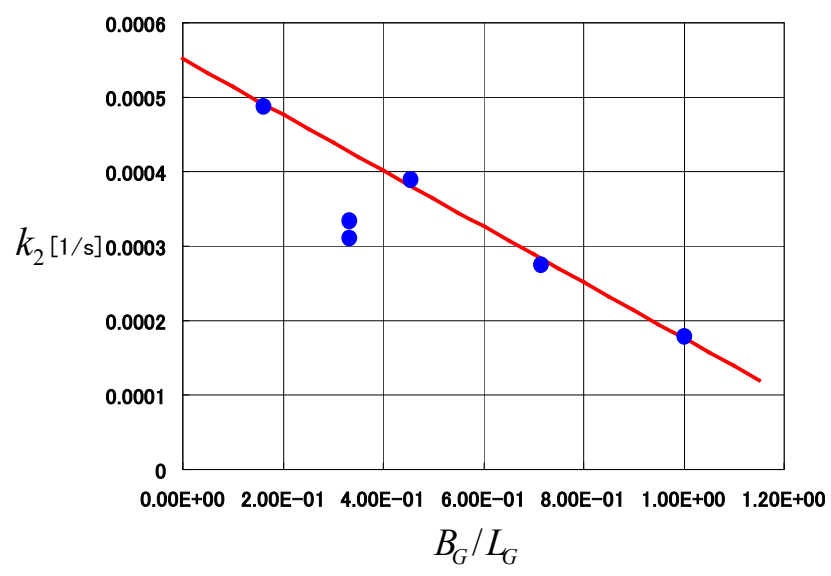

図-4 再ばっ気係数とアスペクト比の関係

再ばっ気係数に占める式(10)の第一項と第二項の割合は, 第二項がおよそ7割から9割を占め, 再ばっ気係数か大き くなるほどその割合も大きくなる．またアスペクト比に 対する変化の傾向が再ばっ気係数と第二項でほぼ一致す る. 第一項はケースごとに大きくは変化しないが，本実 験における $B_{G} / L_{G}=0.71$ のースにおいてやや高い值を示 しており，このケースを過大評価している可能性がある. 本論文ではDOの時間変化が指数変化であることによ り式(15)が成立するとしているが，峳密には必要条件に 過ぎないこと，物質交換係数の影響を評価できていない ことと課題は残寸が，連続水制を伴う開水路では，死水 域と主流部間の質量交換に抵抗があっても従来の方法で 代表的な再ばっ気係数が算出されること，その再ばっ気 係数は水制の間隔に依存して変化することは示された.

\section{5. おわりに}

本研究では連続水制を伴う開水路における自由水面か らのガス輸送速度を測定した. この際，死水域と主流部 間に生じる質量交換の速度がガス輸送に影響を与えうる としてその効果を考慮に入れたモデルを提案し，実験に よる裏づけを試みた。 これにより，連続水制を伴う開水 路において，従来開水路の計測で用いられる方法で代表 的な再ばっ気係数が求まること, その再ばっ気係数は水 制間隔によって変化することが示された．今後，示され た結果に物理的な裏づけを与えること，モデルの適応性 をより厳密に示すことを目標に研究を進めていきたい.

\section{参考文献}

1) 中川研造，川原能久，玉井信行：ワンド内の水理特 性に関する実験的研究, 水工学論文集第39巻, pp.595-600,1995.

2) 木村一郎, 細田尚, 安永良, 村本嘉雄 : 開水路流れ 死水域周辺の水面変動 - 流体混合特性, 水工学論文 集第41巻, pp.771-716,1997.

3) 大本照憲, 平川隆一: 非越流型水制群を伴う開水路 流れの水面振動と乱れ特性, 応用力学論文集,
Vol.4, pp.533-540, 2001.

4) 大本照憲，平川隆一: 非越流型水制群を伴う開水路 流れの水面振動之大規模渦の相互作用, 応用力学論 文集，Vol.5，pp.665-672，2002

5) 藤田一郎, 神田徹, 森田卓光: 開水路流れのPIV及 びLESによる乱流解析，土木学会論文集 II , pp.79$88,1998$.

6) 禰津家久, 鬼束幸樹, 池谷和哉：PIVを用いた開水 路凹部流れにおける水平渦構造の解析，土木学会論 文集，No.677/ II -55,53-61,2001.

7) 八木俊策 : 凹部界面における渦の発生・成長と水交 換機構とその制御法に関する研究，水工学論文集， 第27巻, pp.813-819,1983.

8）冨永晃宏，谷川幸男，久田陽史 : 人口わんどの水交 換機構とその制御法に関する研究，水工学論文集， 第46巻, pp.571-176,2002.

9) Valentine, E. M., and Wood, I. R.: Londitudinal dispersion with dead zone, J. Hydr. Div., ASCE, 103(2), 1527-1553, 1979

10) Uijttewaal, W.S.J., D. Lehmann, A. van Mazijk : Exchange processes between a river and its groyne fields Model experiments, J.H.E,ASCE,1273(11),pp.928936,2001.

11) Weitbrecht,V.,Socolofsky,S.A.,Jirka,G.H.:Experiments on Mass Exchange between Groin Fields and Main Stream in Rivers, J.H.E,ASCE,134(2),pp.173-183,2008.

12) Constantinusce, G., Sukhodolov, A., McCoy, A., : Mass exchange in shallow channel flow with a series of groynes: LES study and comparison with laboratory and field experiments, Environmental Fluid Mechanics, 9, pp.587615, 2009.

13) Jahne, B \& Haussecker, H.: Air/water gas exchange, Annual. Review of Fluid mechanics, Vol.30, pp.443-468, 1998.

14) Herlina: Gas transfer at the air-water interface in a turbulent flow environment, Doctoral thesis, Inst. Hydromech. University of Karlsruhe, 2005.

15) Komori, S., Murakami, Y. and Ueda, H.: The relationship between surface-renewal and bursting motions in an open-channel flow, J. Fluid Mech., 203 (1989) 103-123.

16) Moog, D.B. \& Jirka, G.H. :Air-water gas transfer in uniform channel flow, J. Hydraulic Eng., Vol.125(1), pp.3-10, 1999.

17) Tsumori, H. \& Sugihara, Y.: Length scales of motions that control air/water gas transfer in grid stirred turbulence, Journal Marine Systems, Vol.66, pp.6-18, 2007.

18）平山公明，松尾友矩，今岡正美，平山けい子 : 温度 係数の適合性にもとづく再ばっ気モデルの比較，土 木学会論文集，No.485/ II -26, pp.121-129, 1994

19) Herlina \& Jirka, G. H.: Application of LIF to investigate gas transfer near the air-water interface in a grid-stirred tank, Exps. Fluids, 37 (2004) 341-349.

20）襧津家久, 中山忠暢, 井上理恵 : 水・空気界面での 乱流構造が気体輸送に与える影響, 応用力学論文集 , Vol.2,pp.673-684,1999.

21）山上路生，襧津家久：開水路乱流における自由水面 の流速発散とガス輸送に関する実験的研究，水工学 論文集，第56巻， 2012.

(2012. 9. 30受付) 